\title{
ANNOTATION \\ LIMITATION OF MOBILITY IN MAJOR JOINTS OF 231 SPORTSMEN
}

P. R. TRAVERS, M.B., B.S., D.Phys.Med. and P. G. EVANS

Saint Luke's College, Exeter

\section{Introduction}

A detailed measurement of the range of movement of all the major joints is made as a routine during physiological tests of sportsmen which are carried out at this College. All these tests were made by one of us (P.R.T.). The test

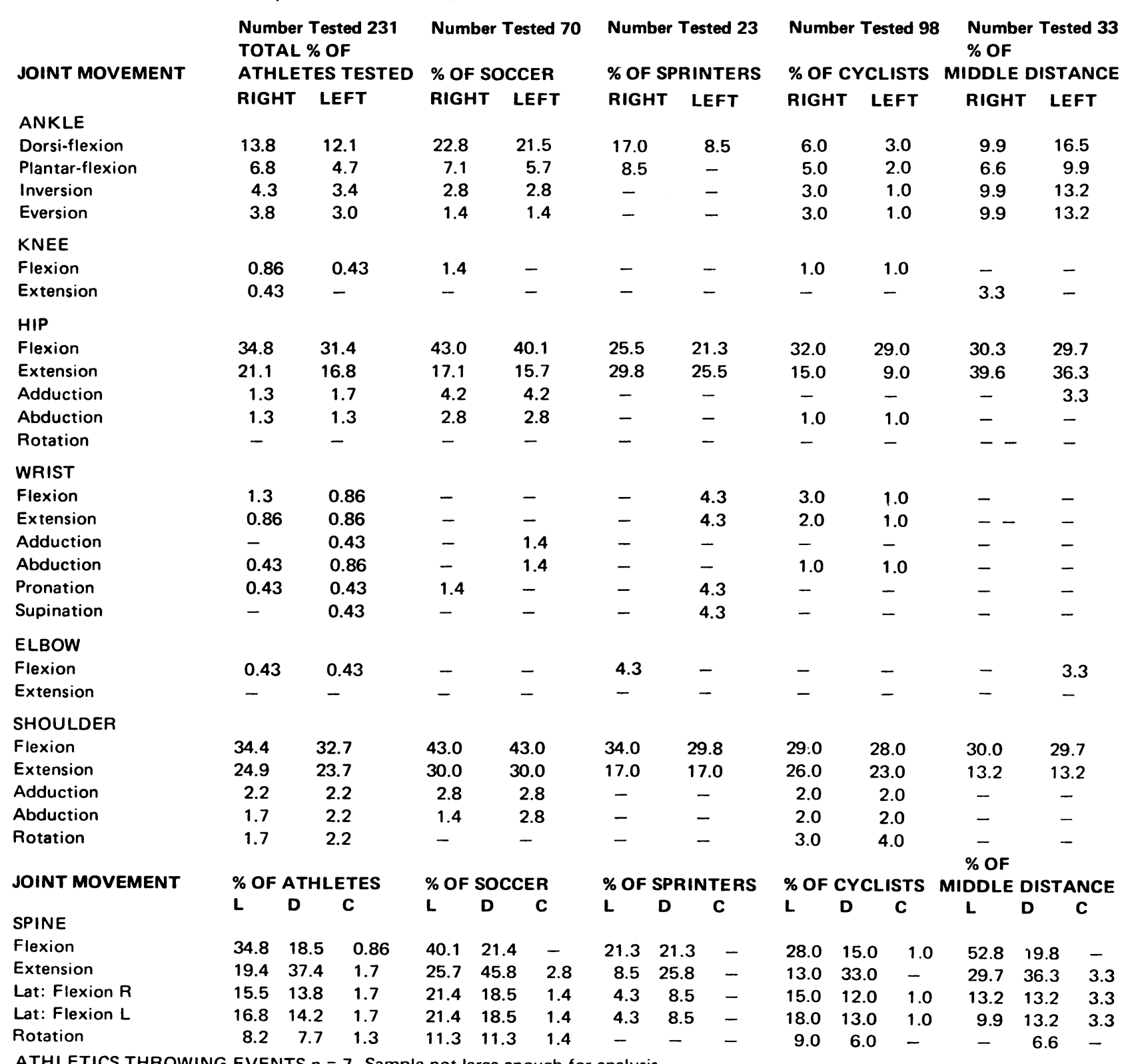

was of the passive range of the joint. A loss of movement of more than $10 \%$ was recorded as a limitation of mobility. 
In this paper we intend merely to present our findings and to comment briefly upon them. Speculation as to the reason for the loss of mobility will not be attempted since the purpose of the original test was merely to record the range of movement and not to investigate the cause. In the same way we do not intend to comment on any change in the range of movement which was found in subsequent tests after specific mobilising exercises had been given. The figures refer to sportsmen presenting themselves for test for the first time. The tests were carried in the Human Performance Laboratory at Saint Luke's College between September 1970 and March 1974.

\section{Discussion}

A surprising number of sportsmen have limitation of mobility in the major joints. There is evidence that each sport shows limitation in specific joints. Thus the percentage of cyclists who have loss of range in the ankle joint is below the average, whilst the percentage of soccer players is above the average.

Limitation of hip mobility is also commonly found; tight hamstrings were found in the majority of those who had limitation of hip flexion.

The shoulder joint was also commonly affected in all sports but, once again the soccer players showed up badly. It is not surprising that the cyclists also showed a higher percentage who had limitation of movement in this joint, although they were still below the average for the whole group.

In the spine, limitation of movement was found mainly in flexion of the lumbar region and in extension of the dorsal spine. Once again the percentage of soccer players with limitation was above the average, but it should be noted that $50 \%$ of middle distance runners tested had limitation of flexion of the lumbar spine.

\section{NEW MEMBERS}

The following were elected by the Executive Committee on March 18th 1976

\section{ORDINARY MEMBERS}

Mr. T. J. H. Ewing, D.P.E., 2 Slade Farm Cottage, KINGHAM, Oxon.

Mr. M. R. Farrally, B.Ed., M.A., D.P.E., 103 Craigie Lea Road, Duntocher, CLYDEBANK, Strathclyde

Mr. D. Gibson, M.S.R.G., 26 Daleview, RAF Headley Court, EPSOM, Surrey

Mrs. Ann Henderson, M.C.S.P., 22 Racecourse View, AYR

Mr. J. L. Humphreys, M.Ed., 55 The Drive, Alwoodley, LEEDS 17

Mr. R. G. Lowhon, M.C.S.P., 16 Daleview, Headley Court, EPSOM, Surrey

Miss Heather McLaren, M.C.S.P., D.M.R.C., The Hermitage, CHESTER-LE-STREET, Co. Durham

Mr. W. D. Mackay, M.C.S.P., 3 Hayes Cottages, Church Lane, Headley, EPSOM, Surrey

Dr. G. L. J. Roblings, Glynhir, Magor Road, Langstone, NEWPORT, Gwent

Dr. R. W. Shepherd, 80 Woodland Road, Coresyceiliog, CWMBRAN, Gwent

Dr. I. R. Smith, 3 Cunliffe Close, RAF Headley Court, EPSOM, Surrey

Mr. R. Stone, D.P.E., 96 Lindin House, Common Road, Langley, SLOUGH, Bucks.

Proposed by:

P. Sperryn

J. Moncur

J. Deary

H. Robson

D. Brodie

J. Deary

H. Robson

J. Deary

D. G. Jones

H. Robson

J. Deary

H. Robson

\section{JOINT MEMBERS}

Ms Lorna Sperryn, M.C.S.P., 63 Alric Avenue, NEW MALDEN, Surrey

P. Sperryn

\section{TRANSFER FROM JOINT TO ORDINARY MEMBERSHIP}

Mrs. Margaret Pearson, M.C.S.P., 344 Chorley New Road, BOLTON, Greater Manchester

H. Robson

\section{AFFILIATED MEMBERSHIP}

Edinburgh University Health Service, Bristo Street, EDINBURGH EH8 9AL

J. Moncur Rep: Mrs. R. Smith, M.C.S.P. 